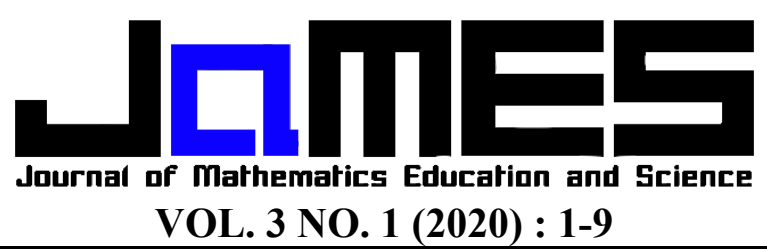

p-ISSN: 2621-1203 | https://doi.org/10.32665/james.v3i1.86

e-ISSN: 2621-1211

\title{
PENGEMBAGAN LEMBAR KERJA SISWA BERBASIS KONTEKSTUAL TEACHING AND LEARNING UNTUK TUNARUNGU
}

\author{
Muhammad Iqbal ${ }^{1}$, Bambang Sri Anggoro ${ }^{2}$, Rosida Rakhmawati ${ }^{3}$ \\ Universitas Islam Negeri Raden Intan Lampung, muhammad.iqbal.aya@gmail.com ${ }^{1}$ \\ Universitas Islam Negeri Raden Intan Lampung, bambangsrianggoro@radenintan.ac.id ${ }^{2}$ \\ Universitas Islam Negeri Raden Intan Lampung, rosidarakhmawati@,radenintan.ac.id ${ }^{3}$ \\ Received : 31 Maret 2019, Revised : 8 Oktober 2020, Accepted : 23 April 2020 \\ (C) Mathematics Education Unugiri 2020
}

\begin{abstract}
The purpose of this study is to develop worksheets based on contextual teaching and learning for the deaf. The method that will be used is the method of research and development. The development procedure used is the procedure of borg and gall. The technique of data collection used is random class techniques. The sample used is the SMALB Dharma bhakti dharma pertiwi students. The data collection techniques used were interviews, observations and questionnaires. The data analysis technique used is descriptive qualitative and descriptive quantitative. The main results of this research and development are LKS based on contextual teaching and learning for the deaf. Based on the results of the validation to the material experts and LKS media experts developed, the criteria were very feasible to use. Judging from the LKS field trials that were developed, obtaining very interesting criteria to be used in mathematics learning. Based on this matter, it is concluded that mathematics student books for students with inquiry approaches for students developed for the deaf are very feasible and very interesting to be used in mathematics learning for deaf students.
\end{abstract}

\section{Keywords: Student Worksheets, Contextual Teaching and Learning, Deaf Children}

\begin{abstract}
Abstrak
Tujuan penelitian ini adalah mengembangkan LKS berbasis kontekstual teaching and learning untuk tunarungu. Metode yang akan digunakan adalah metode penelitian dan pengembangan. Prosedur pengembangan yang digunakan adalah prosedur dari borg and gall. Tehnik pengumpulan data yang digunakan adalah tehnik acak kelas. Sampel yang digunakan adalah siswa SMALB Dharma bhakti dharma pertiwi. Tehnik pengembilan data yang digunakan adalah wawancara, observasi dan angket. tehnik analisis data yang digunakan adalah deskristif kualitatif dan deskristif kuantitatif. Hasil utama dari penelitian dan pengembangan ini adalah LKS berbasis kontekstual teaching and learning untuk tunarungu. Berdasarkan hasil validasi kepada ahli materi dan ahli media LKS yang dikembangkan memperoleh kriteria sangat layak digunakan. Ditinjau dari uji coba lapangan LKS yang dikembankan memperoleh kriteria sangat menarik untuk digunakan dalam pembeljaran matematika. Berdasarkan hal ini daopat disimpulkan bahwa buku siswa matematika untuk siswa dengan pendekatan inkuiri untuk siswa yang dikembangkan untuk tunarungu sangat layak dan sangat menarik untuk digunakan dalam pemebalajaran matematika siswa tunarungu.
\end{abstract}

Kata Kunci: Lembar Kerja Siswa, Kontekstual Teaching and Learning, Anak Tunarungu

\section{Pendahuluan}

Pendidikan merupakan sarana untuk menuju kepada pertumbuhan dan perkembangan bangsa. Pendidikan juga merupakan investasi sumber daya manusia jangka panjang yang mem-punyai nilai strategis bagi kelangsungan 
peradaban manusia di dunia [1]. Maka dari itu pendidikan menjadi salah satu modal penting untuk memajukan sebuah bangsa karena kesejahteraan dan kemajuan sebuah bangsa dapat dilihat dari tingkat pendidikannya. Pendidikan memegang peranan penting dalam menciptakan individu berkualitas [2]. Menurut [3] hal tersebut menyebabkan dunia pendidikan memerlukan inovasi-inovasi yang sesuai dengan kemajuan ilmu pengetahuan dan teknologi tanpa mengabaikan nilai-nilai kemanusiaan. Pendidikan juga dipandang sebagai sarana untuk melahirkan insan-insan yang cerdas, kreatif, terampil, bertanggung jawab, produktif dan berbudi pekerti luhur. Salah satu pendidikan yang dapat mengembangkan kemampuan serta kreatifitas adalah pendidikan matematika yang berarti didalamnya terdapat pelajaran matematika [4].

Pelajaran matematika merupakan salah satu mata pelajaran yang memiliki manfaat besar dalam kehidupan. Matematika memberikan kesempatan kepada siswa untuk melatih mental mereka dan akan berpengaruh terhadap perkembangan intelektual mereka [5]. Melalui pelajaran matematika siswa akan mampu belajar untuk memperoleh pengetahuan secara sistematis [6]. Salah satu tujuan pembelajaran matematika adalah peserta didik dapat menerapkan matematika secara tepat dalam kehidupan sehari-hari serta dalam berbagai ilmu pengetahuan, guna mempersiapkan dan meningkatkan kualitas sumber daya manusia, sehingga terwujudlah pendidikan matematika yang baik [7]. Selain itu juga pelajaran matematika itu diberikan kepada seluruh manusia tanpa memandang anak, baik normal maupun anak yang berkebutuhan khusus. Dengan kata lain, pelayanan pendidikan tidak membedakan fisik, emosi, sosial dan intelektual. Berkenaan dengan itu, anak berkebutuhan khusus juga memiliki potensi dan kemampuan yang masih bisa dikembangkan. Banyak potensi yang dapat di kembangkan dari masing-masing individu dari ke kurangan yang mereka miliki, seperti istilah mengatakan carilah potensi mereka di balik banyak hambatan mereka [8].

Dalam penelitian ini peneliti melihat pada anak tunarungu, tunarungu adalah Istilah umum yang menunjukkan kesulitan mendengar, yang meliputi keseluruhan kesulitan mendengar dari yang ringan sampai yang berat, di golongkan kedalam bagian tuli dan kurang dengar [9]. Oleh karena itu mereka mengalami hambatan dalam proses informasi bahasa melalui pendengaran. Dampak terhadap kehidupannya secara kompleks mengandung arti bahwa akibat ketunarunguan. Maka perkembangan anak menjadi terhambat. Yang perlu diperhatikan akibat dari ketunarunguan ialah hambatan dalam berkomunikasi, sedangkan komunikasi merupakan hal yang sangat penting dalam kehidupan sehari-hari. Kenyataan bahwa anak tunarungu tidak dapat mendengar membuatnya mengalami kesulitan untuk memahami bahasa yang di ucapkan oleh orang lain. Sehingga dalam pembelajaran tak diherankan tuna rungu akan lebih mengalami kesulitan dalam memahami pelajaran yang tersampaikan. Seperti hal nya yang telah dipaparkan oleh [10] hasil belajar siswa penyandang tuna runga masih sangat jauh dibawah rata-rata, hal ini dakarenakan kurangnya perhatian para pendidik dengan siswa yang butuh penangan lebih dalam pembelajaran.

Sama hal nya yang terjadi di SMALB Dharma Bhakti Dharma Pertiwi, berdasarkan hasil observasi peneliti diperoleh dokumentasi hasil belajar peserta didik masih terdapat 4 peserta didik yang masih belum mencapai nilai Kriteria Ketuntasan Minimal (KKM) yaitu 70,00. Maka dapat disimpulkan bahwa hanya $42,84 \%$ dari 7 peserta didik yang nilainya sudah mencapai KKM dan $57,16 \%$ belum mencapai KKM. Dilihat dari nilai diatas dapat dikatakan bahwa ada suatu permasalahan yang cukup serius pada sistem atau proses pembelajaran yang ada di SMALBD harma Bhakti Dharma Pertiwi dan perlu untuk diperhatikan, karena persentase siswa yang tuntas masih tergolong sangat rendah. Dimana belajar adalah kegiatan yang berperoses dan merupakan unsur yang 
sangat fundamental dalam penyelenggaraan setiap jenis dan jenjang pendidikan. Ini berarti, bahwa berhasil atau gagalnya pencapaian tujuan pendidikan itu amat bergantung pada proses belajar yang dialami siswa baik ketika ia berada di sekolah maupun di lingkungan rumah atau keluarganya sendiri [11].

Menurut [12] dampak langsung dari ketunarunguan adalah terhambatnya komunikasi verbal/ lisan, baik secara ekspresif (berbicara) maupun reseptif (memahami pembicaraan orang lain), sehingga sulit berkomunikasi dengan lingkungan orang mendengar yang lazim menggunakan bahasa verbal sebagai alat komunikasi. Hambatan dalam berkomunikasi tersebut, berakibat juga pada hambatan dalam proses pendidikan dan pembelajaran anak tunarungu. Dengan demikian dalam pembelajaran, anak tunarungu lebih mengandalkan indera penglihatan [9].

Merujuk indra penglihatan yang dapat diandalkan dalam pembelajaran tunarungu, peneliti akan mengembangkan sebuah LKS khusus untuk tuna rungu. Menurut [13] LKS yang dikembangkan semenarik mungkin akan mampu mempengaruhi psikomotorik peserta didik dalam proses belajar, terlebih lagi pada peserta didik yang mengalami tunarungu yang butuh penanganan lebih. Selain itu merujuk hasil penelitian (Afifah, 2018) didapatkan bahwa Lembar Kerja Peserta didik dapat membantu peserta didik dalam meningkatkan kemampuan penalarannya dengan bantuan penglihatan yang dapat dinalar seperti gambargambar yang didesain didalam LKS. Sejalan dengan yang diungkapkan oleh [12] mengungkapkan bahwa khusus untuk tuna rungu akan lebih efektif pembelajaran jika dengan memanfaatkan indra penglihatan seperti meggunakan media pembelajaran, buku, lks dll. Sehingga dalam hal ini peneliti tertarik untuk mengembagkan sebuah LKS khusus untuk peserta didik tuna rungu.

Agar lebih efektif, LKS yang dikembangkan berbasis kontekstual. Sehingga peserta didik langsung bisa mencerna dan menggambarkan permasalahan yang akan dihadapi dalam kehidupan nyata. Dalam hal peneliti akan menggunakan metode yang digunakan adalah (Contextual Teaching and Learning). Pembelajaran kontekstual (Contextual Teaching and Learning) merupakan konsep belajar yang membantu guru mengaitkan antara materi yang diajarkan dengan situasi dunia nyata siswa dan mendorong siswa membuat hubungan antara pengetahuan yang dimilikinya dengan penerapannya dalam kehidupan mereka sebagai anggota keluarga dan masyarakat [14]. Selain itu penggunaan metode ini sekaligus menjadi keterbaharuan peneliti dengan penelitian sebelumnya, karena belum pernah dilakukan pengembangan LKS berbasis Contextual Teaching and Learning untuk anak tunarungu.

\section{Metode Penelitian}

Penelitian dalam artikel ini menggunakan metode penelitian dan pengembangan (Research and Development) karena penelitian ini akan menghasilkan produk tertentu. Prosedur yang digunakan dalam penelitian dan pengembangan ini adalah prosedur dari borg and gall.

1. Potensi Masalah

2. Mengumpulkan informasi

3. Desain produk

4. Validasi desain

5. Revisi produk

6. Uji coba pemakaian

7. Revisi produk

8. Uji coba produk

9. Revisi produk

\section{Produksi Massa}

Adapun prosedur yang digunakan hanya 7 tahap dari 10 tahap dar prosedur tersebut. Pembatasan ini dilakukan karena sesuai dengan tujuan penelitian yang dilakukan oleh peneliti. Tehnik pengumpulan data yang digunakan adalah observasi, penyebaran angket dan wawancara. Angket yang digunakan adalah angket validasi media dan angket respon peserta didik. Tehnik pengambilan sampel yatu tehnik random sampling, adapun sample yang digunakan peserta didik kelas SMALB Dharma 
Bhakti Dharma Pertiwi. Instrumen pengumpulan data dengan menggunakan lembar angket kelayakan dan kemenarikan respon siswa terhadap media yang dikembangka. Teknik analisis data yang digunakan dalam penelitian dan pengembangan yaitu, deskriptif kuantitatif untuk mengolah data dalam bentuk skor dari penilaian oleh validator dan respon siswa, sedangkan deskriptif kualitatif untuk mendeskripsikan data berupa komentar saran perbaikan dari validator. Adapun table yang digunakan untuk menginterpretasikan hasil angket dapat dilihat pada Tabel 1.

Tabel 1. Interpretasi Hasil Angket (Herdiyanto, 2018)

\begin{tabular}{cccc}
\hline $\begin{array}{c}\text { Skor } \\
\text { Presentase }\end{array}$ & $\begin{array}{c}\text { Interetasi } \\
\text { Para Ahli }\end{array}$ & $\begin{array}{c}\text { Interpretasi } \\
\text { Peserta didik }\end{array}$ & Keterangan \\
\hline $75 \% \leq \mathrm{P} \leq$ & Sangat & Sangat & Tidak Revisi \\
$100 \%$ & Layak & Menarik & Revisi \\
$50 \% \leq \mathrm{P}<$ & Layak & Menarik & Sebagian \\
$75 \%$ & Tidak & Tidak & Revisi Kajian \\
$25 \% \leq \mathrm{P}<$ & Layak & Menarik & Ulang Produk \\
$50 \%$ & Sangat & Sangat Tidak & Revisi Total \\
$0 \% \leq \mathrm{P}<$ & Tidak & Menarik & \\
$25 \%$ & Layak & &
\end{tabular}

\section{Hasil Penelitian}

Hasil utama dari penelitian dan pengembangan ini adalah Lembar Kerja Siswa (LKS) berbasis kontekstual untuk kelas $\mathrm{X}$ SMALB Dharma Bhakti Dharma Pertiwi khusus Tunarungu. Penelitian dan pengembangan ini dilakukan dengan menggunakan prosedur pengembangan menurut sugiyono yang dilakukan dari tahap 1 hingga tahap 7. Data hasil setiap tahapan prosedur penelitian dan pengembangan yang dilakukan adalah sebagai berikut :

\section{a. Potensi dan masalah}

Pada tahap ini yang penting dilakukan adalah analisis kebutuhan terhadap produk yang akan dikembangkan melalui wawancara terhadap Identifikasi (learning obstacle) yaitu identifikasi kesulitan belajar, untuk mengetahui kesulitan belajar peserta didik maka penulis melakukan wawancara terhadap pendidik wawancara dan observasi terhadap guru mata pelajaran matematika di SMALB Dharma Bhakti Dharma Pertiwi khusus tunarungu dan observasi terhadap beberapa sumber belajar yang dipakai di SMALB mengenai pembelajaran matematika disekolah tersebut. Dari hasil wawancara dan observasi dapat disimpulkan beberapa masalah sebagai berikut:

1) Buku yang digunakan sudah berbentuk paket seperti Modul. Semua

2) materi pembelajaran dijadikan menjadi satu, seperti olahraga, kesenian dan matematika. Soal masih berbentuk umum dan belum merujuk pada konsentrasi materi matematika.

3) Siswa yang nilai akhir ujian matematika kelas VII tergolong rendah, $57,16 \%$ belum mencapai KKM.

4) Belum tersedianya Lembar Kerja Siswa (LKS) berbasis kontekstual khusus untuk siswa tunarungu.

Disisi lain tehnik pengajaran yang digunakan oleh guru dari wawancara hanya berkutat dengan pembelajaran metode konvensional, tanpa adanya inisiatiff menggunakan cara pembelajaran yang dapat membuat siswa termotivasi dalam pemvelajaran pook bahasan aritmetika. Sehingga siswa belajar dapat menyelesaikan masalah dengan cepat dan benar seperti yang diharapkan oleh para guru disekolah. Selain itu berdasarkan data yang didapatkan kegemaran siswa membaca dan ingin cepat menyelesaikan masalah yang diberikan oleh guru. Berdasarkan hal ini maka penulis melihat adanya potensi untuk melakukan inovasi terbaru dalam pembelajaran matematika pada pokok bahasan aritmetika. Maka peneliti ingin mengembangkan sebuah Lembar Kerja Siswa (LKS) berbasis kontekstual untuk kelas X SMALB Dharma Bhakti Dharma Pertiwi khusus Tunarungu.

\section{b. Mengumpulkan informasi}

Dalam proses pengembangan produk ini, peneliti mengumpulkan informasi berupa teori pendukung untuk produk yang akan 
dibuat. Peneliti mengumpulkan beberapa buku ajar yang digunakan di sekolah baik berupa silabus pembelajaran, buku paket, buku sekolah elektronik (BSE), serta sumbersumber lain yang relevan dengan penelitian.

\section{c. Desain produk}

Tahap ini merupakan tahap dimana semua objek bahan ajar dibuat. Pada proses ini, peneliti tidak serta merta merubah isi materi yang ada, namun menggabungkan materi dari beberapa sumber yang relevan dengan materi yang akan dikembangkan. Pengembangan produk didesain mengikuti langkah-langkah pendekatan kontekstual dengan memperhatikan beberapa point standar kelayakan bahan ajar yang terdiri dari standar kelayakan isi, standar kelayakan penyajian, dan standar kelayakan kebahasan. Selain itu SK dan KD menjadi acuan dalam mengembangkan Lembar Kerja Siswa (LKS). LKS matematika berbasis kontekstual berarti dalam LKS dikembangkan dengan menggunakan langkah-langkah kontekstual yaitu:

\section{1) Kontruktivisme}

Konstruktivisme lebih menekankan bahwa pembelajaran tidak sekedar menghafal atau mengingat pengetahuan. Akan tetapi merupakan suatu proses belajar mengajar dimana siswa sendiri aktif secara mental. Yaitu membangun pemahaman mereka sendiri dari pengalaman baru berdasarkan pada pengetahuan awal yang telah mereka miliki. Sehingga dalam pengembangan LKS ini disetiap sub bab materi diawal dengan kegiatan konstruktivisme.

2) Bertanya (questioning)

Bertanya dalam pembelajaran dipandang sebagai kegiatan untuk mendorong, membimbing, dan menilai kemampuan berpikir siswa. Setelah siswa mendapatkan informasi atau pengetahuan baru dari kegiatan kontruktivisme, untuk menciptakan aktivitas pembelajaran yang lebih aktif maka dalam LKS ini dilanjutkan dengan kegiatan bertanya.

3) Menemukan (inquiri)
Menemukan merupakan bagian inti dari aktivitas pembelajaran berbasis kontekstual. Pengetahuan dan keterampilan yang diperoleh siswa bukan dari hasil mengingat fakta-fakta melainkan dari hasil menemukan sendiri.

4) Learning community

Setelah siswa mendapatkan informasi baru berdasarkan aktivitas penemuan, untuk memantapkan pemahaman terhadap suatu konsep baru tersebut, akan lebih efektif jika diadakannya diskusi kelompok. Sehingga dalam LKS ini setelah kegiatan penemuan dilanjutkan dengan kegiatan berdiskusi.

5) Pemodelan (Modeling)

Pemodelan adalah menampilkan model yang bisa dilihat, dirasakan, dan bahkan bisa ditiru oleh siswa. Tidak hanya guru yang dapat menjadi model dalam sebuah aktivitas belajar, tetapi siswa juga dapat menjadi model agar dapat ditiru oleh siswa lainnya. Dalam LKS ini agar siswa dapat berperan lebih aktif dalam kegiatan di kelas maka siswa akan dirangsang agar berani tampil kedepan menyampaikan pendapatnya.

\section{6) Refleksi (Reflection)}

Refleksi adalah cara berpikir tentang apa yang telah dipelajari. Refleksi juga merupakan gambaran terhadap kegiatan atau pengetahuan yang baru saja diterima oleh siswa. Dengan adanya kegiatan merefleksi aktivitas belajar, siswa akan menyadari bahwa pengetahuan yang baru diperolehnya merupakan pengayaan atau revisi dari pengetahuan yang telah dimiliki sebelumnya. Hal ini akan membuat siswa lebih terbuka terhadap pengetahuan-pengetahuan baru. Penilaian yang Sebenarnya (Authentic Assessment)

Authentic Assessment adalah proses pengumpulan berbagai data yang bisa memberikan gambaran atau informasi tentang perkembangan pengalaman belajar siswa. Berikut ini merupakan salah satu contoh penilaian autentik yang terdapat dalam LKS yang dikembangkan.

\section{d. Validasi desain}


Setelah bahan ajar didesain dan dikembangkan maka selanjutnya tahap validasi desain. Validasi desain digunakan untuk melihat kelayakan media yang dikembangkan, selain itu bertujuan untuk melihat kekurangan media. Validasi desain dilakukan kepada Ahli materi dan Ahli media memiliki kriteria dalam penentuan subyek ahli, yaitu berpengalaman di bidangnya, Berpendidikan minimal S2 atau sedang menempuh pendidikan S2. Selain itu validasi juga dilakukan oleh 2 praktisi yaitu guru Matematika dan guru Bahasa. Validasi dilakukan dengan menilai media melalui angket skala likert yang sesuai dengan bahan ajar yang digunakan.

\section{1) Ahli materi}

Validasi ahli materi dilakukan kepada 3 ahli yang ahli dibidang materi. Hasil dari validasi ahli materi dapat dilihat pada table berikut:

Tabel 2. Hasil validasi ahli materi tahap 1

\begin{tabular}{cccccc}
\hline Aspek & $\begin{array}{c}\text { Vali } \\
\text { dator1 }\end{array}$ & $\begin{array}{c}\text { Vali } \\
\text { dator2 }\end{array}$ & $\begin{array}{c}\text { Vali } \\
\text { dator3 }\end{array}$ & $\begin{array}{c}\text { Rata- } \\
\text { rata }\end{array}$ & $\begin{array}{c}\text { Krite- } \\
\text { ria }\end{array}$ \\
\hline $\begin{array}{c}\text { kelayakan } \\
\text { isi }\end{array}$ & $67,5 \%$ & $72,5 \%$ & $75 \%$ & $72 \%$ & layak \\
$\begin{array}{c}\text { Kebaha- } \\
\text { saan }\end{array}$ & $75 \%$ & $75 \%$ & $75 \%$ & $75 \%$ & layak \\
\hline
\end{tabular}

Berdasarkan validasi ahli tahap 1 dilakukan, media sudah mendapatkan kriteria layak digunakan. Namun disisi lain para ahli memberi masukan dan saran yang harus diperbaiki agar media benar benar valid dan sangat layak digunakan saat dilakukan uji coba. Setelah bahan ajar diperabaiki sesuai saran dan masukan para ahli maka dilakukan validasi tahap 2. Hasil validasi tahap 2 dapat dilihat pada Tabel 3.

Tabel 3. Hasil validasi ahli materi tahap 2.

\begin{tabular}{cccccc}
\hline Aspek & $\begin{array}{c}\text { Vali } \\
\text { dator1 }\end{array}$ & $\begin{array}{c}\text { Vali } \\
\text { dator2 }\end{array}$ & $\begin{array}{c}\text { Vali } \\
\text { dator3 }\end{array}$ & $\begin{array}{c}\text { Rata- } \\
\text { rata }\end{array}$ & $\begin{array}{c}\text { Krite- } \\
\text { ria }\end{array}$ \\
\hline $\begin{array}{c}\text { kelayakan } \\
\text { isi }\end{array}$ & $80 \%$ & $75,5 \%$ & $75 \%$ & $76,5 \%$ & $\begin{array}{c}\text { Sangat } \\
\text { layak }\end{array}$ \\
$\begin{array}{c}\text { Kebaha- } \\
\text { saan }\end{array}$ & $78,5 \%$ & $80,5 \%$ & $80 \%$ & $79,6 \%$ & $\begin{array}{c}\text { Sangat } \\
\text { layak }\end{array}$ \\
\hline
\end{tabular}

Berdasarkan Tabel 3. Hasil validasi tahap 2, hasil validasi yang diperoleh pada aspek kelayak isi mencapai rata-rata presentase $76,5 \%$ dan pada aspek kebahasan mencapai rata-rata $79,6 \%$. Beradasarkan hal ini dapat dilihat validasi tahap 2 mengalami peningkatan pada masing-masing aspek dengan kriteria sangat layak. Berdasarkan hasil ini maka media sudah sangat layak dilakukan uji coba lapangan dan tidak lagi dilakukan perbaikan kepada media berdasarkan ahli materi atau materi yang telah digunakan dalam media.

2) Ahli media

Validasi ahli media dilakukan kepada 2 ahli yang ahli dibidang media. Hasil dari validasi ahli media dapat dilihat pada tabel berikut:

Tabel 4. hasil validasi ahli media tahap 1

\begin{tabular}{ccccc}
\hline Aspek & $\begin{array}{c}\text { Vali } \\
\text { dator1 }\end{array}$ & $\begin{array}{c}\text { Vali } \\
\text { dator2 }\end{array}$ & $\begin{array}{c}\text { Rata- } \\
\text { rata }\end{array}$ & Kriteria \\
\hline Cover lks & $75 \%$ & $68,2 \%$ & $71,6 \%$ & $\begin{array}{c}\text { Cukup } \\
\text { layak }\end{array}$ \\
$\begin{array}{c}\text { Ukuran lks } \\
\begin{array}{c}\text { Penyajian } \\
\text { lks }\end{array}\end{array}$ & $72,5 \%$ & $70,6 \%$ & $71,55 \%$ & $\begin{array}{c}\text { Cukup } \\
\text { layak }\end{array}$ \\
\hline
\end{tabular}

Berdasarkan Tabel 4. Hasil validasi kepada ahli media tahap 1 pada aspek cover buku diperoleh presentase rata-rata $71,6 \% \%$, pada aspek ukuran buku peroleh presentase rata-rata $71,55 \%$ dan pada aspek penyajian buku diperoleh presentase rata-rata $69 \%$ dengan masing-masing kriteria cukup layak atau revisi sebagian. Maka peneliti melakukan perbaikan media sesuai masukan dan saran para ahli media. Setelah media derbaiki maka dilakukan validasi tahap 2. Hasil dari validasi tahap 2 sebagai berikut:

Table 5. hasil validasi ahli media tahap 2

\begin{tabular}{ccccc}
\hline Aspek & $\begin{array}{c}\text { Vali } \\
\text { dator1 }\end{array}$ & $\begin{array}{c}\text { Vali } \\
\text { dator2 }\end{array}$ & $\begin{array}{c}\text { Rata- } \\
\text { rata }\end{array}$ & Kriteria \\
\hline Cover lks & $79,3 \%$ & $75,2 \%$ & $77,25 \%$ & $\begin{array}{c}\text { Sangat } \\
\text { layak }\end{array}$ \\
Ukuran lks & $80,5 \%$ & $79,6 \%$ & $80,5 \%$ & $\begin{array}{c}\text { Sangat } \\
\text { layak }\end{array}$ \\
Penyajian lks & $80,5 \%$ & $80 \%$ & $80,25 \%$ & $\begin{array}{c}\text { Sangat } \\
\text { layak }\end{array}$ \\
\hline
\end{tabular}


Berdasarkan Tabel 5. Hasil validasi tahap 2, masing-masing aspek mengalami peningkatan yaitu memperoleh presentase rata-rata diatas atau sama dengan 79,33\% dengan kriteria sangat layak. berdasarkan hal ini dapat siimpulkan bahwa media yang dierbaiki sudah sesuai dengan saran dan masukan oleh ahli materi. Selanjutnya media yang dikembangkan sangat layak untuk menjadi media pembelajaran dan dilakukan uji coba lapangan.

\section{e. Perbaikan produk}

Perbaikan produk penting dilakukan pada proses tahap validasi.

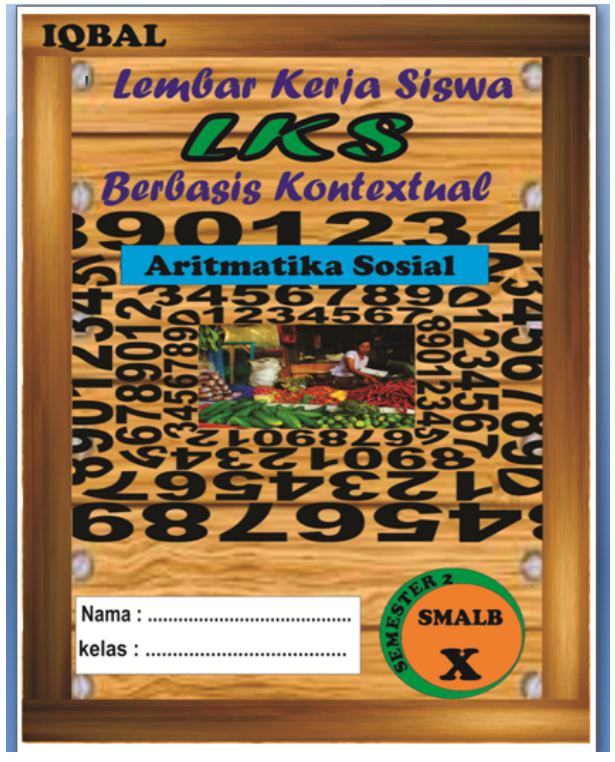

Gambar 4. Cover sebelum revisi

Karena kelayakan produk yang dikembangkan untuk digunakan sebagai media pembelajaran matematika haruslah sangat-sangat valid dan membuat peserta didik mudah dalam mempelajarinya. Perbaikan produk dilakukan sesuai dengan masukan dan saran oleh para validator. Perbaikan yang dilakukan diantaranya ditampilkan pada Gambar 5 :

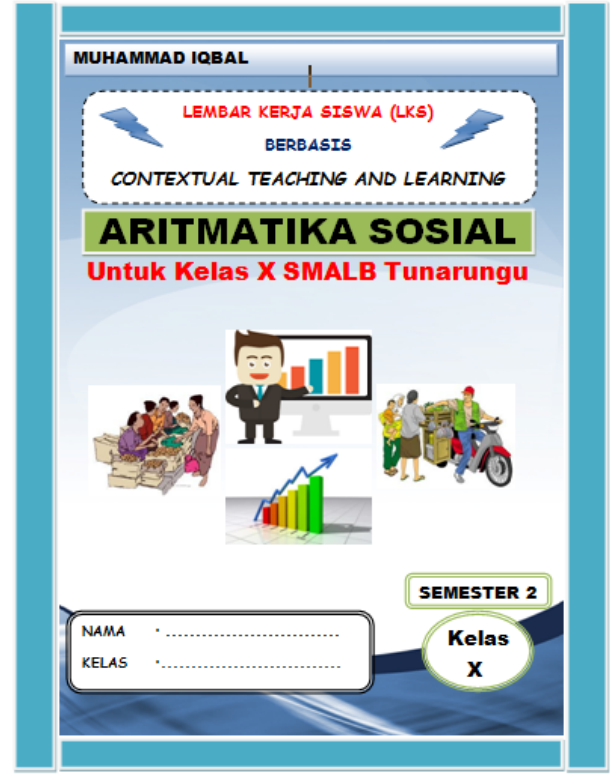

Gambar 5. Cover sesudah revisi

\section{f. Uji coba produk}

Setelah melakukan uji coba kelompok kecil, kemudian produk diuji cobakan kembali ke uji coba lapangan. Uji coba lapangan ini dilakukan untuk meyakinkan data dan mengetahui kemenarikan produk secara luas. Responden pada uji kelompok besar ini berjumlah 15 peserta didik SLB Dharma Bhakti Dharma Pertiwi Kemiling Bandar Lampung kelas VII dengan cara memberi angket untuk mengetahui respon peserta didik terhadap kemenarikan media pembelajaran. Hasil uji coba lapangan di SLB Dharma Bhakti Dharma Pertiwi Kemiling Bandar Lampung memperoleh rata-rata $90.15 \%$ dengan kriteria interpretasi yang di capai yaitu "Sangat Baik". Hal ini berarti bahan ajar (buku siswa) yang dikembangkan oleh peneliti mempunyai kriteria menarik untuk digunakan sebagai alat bantu dalam kegiatan belajar mengajar pada materi bangun datar untuk kelas VII SMPLB.

Tabel 7. Hasil Rata- Rata Uji Coba Peserta didik Angket Tingkat Kepuasan

\begin{tabular}{ccc}
\hline Nama Sekolah & $\begin{array}{c}\text { Uji Coba } \\
\text { Skala Kecil }\end{array}$ & $\begin{array}{c}\text { Uji Coba } \\
\text { Skala besar }\end{array}$ \\
\hline $\begin{array}{c}\text { SLB Dharma Bhakti } \\
\text { Dharma Pertiwi }\end{array}$ & $85.00 \%$ & $93.15 \%$ \\
\hline
\end{tabular}


Dari hasil uji coba media pembelajaran yang di telah dilakukan di SLB Dharma Bhakti Dharma Pertiwi Kemilimng Bandar Lampung terlihat bahwa rata- rata hasil uji coba juga meningkat dimana pada uji coba skala kecil rata- ratanya adalah $85.00 \%$ dengan kriteria "Baik" dan uji coba lapangan 93.15\% dengan kriteria "Sangat Baik". Dari hasil uji coba di sekolah tersebut terlihat hasilnya meningkat dari kriteria "Baik", dan di skala besar meningkat menjadi memiliki kriteria "Sangat Baik", jadi produk bahan ajar (buku siswa) tersebut layak digunakan.

\section{g. Revisi produk}

Setelah dilakukan uji coba kelompok kecil dan uji coba kelompok besar untuk mengetahui kemenarikan bahan ajar (buku siswa), produk dikatakan menarik. Setelah melalukan revisi yang dilakukan 2 tahap oleh 3 validator ahli materi, satu ahli media, dan satu ahli bahasa 3 dosen UIN Raden Intan lampung, 2 guru SMALB Dharma Bhakti Dharma Pertiwi khusus anak tunarungu Kemiling Bandar Lampung. Pada penelitian ini tahap revisi adalah tahap terakhir. LKS yang telah direvisi akan menjadi buku siswa matematika yang telah memenuhi standar kemenarikan media pembelajaran yang ditinjau dari sisi materi diantaranya kesesuaian materi, keakuratan materi, membantu dalam memecahkan masalah dalam materi, kelayakan penyajian bahan ajar, kelayakan kebahasaan dalam bahan ajar.

Berdasarkan hal ini maka dapat diambil makna bahwa bahan ajar atau media pembelajaran sangat penting dalam proses membantu peseta didik dalam memahami materi baik peserta didik normal maupun peserta didik yang mengalami kekurangan. Hal ini terbukti dari respond dan antusian peserta didik betapa senangnya belajar dengan hal-hal yang baru dan tidak berkutat dengan itu saja. Pendapat peneliti sejalan dengan yang disampaikan oleh (Khoiriyah \& Rizki, 2017) bahwa bahan ajar atau media pembelajaran mendapatkan respon yang baik oleh peserta didik. Selain itu (Avianty \& Cipta, 2018) mengungkapkan bahwa bahan ajar atau media pembelajaran dapat memudahkan peserta didik dalam memahami pelajaran yang disampaikan. Menurut (Masykur dkk., 2017) bahan ajar yang digunakan dalam pembelajaran akan meningkatkan hasil belajar peseta didik.

\section{Penutup}

\section{Kesimpulan}

Berdasarkan hasil penelitian dan pengembangan yang dilakukan maka dapat disimpulkan penelitian ini telah menghasilkan sebuah lembar kerja siswa berbasis contextual leraning and teaching untuk tunarungu. Berdasarkan hasil validasi kepada ahli materi dan ahli media LKS yang dikembangkan memperoleh kriteria sangat layak digunakan. Ditinjau dari uji coba lapangan LKS yang dikembankan memperoleh kriteria sangat menarik untuk digunakan dalam pembeljaran matematika. Adapun hasil belajar peserta didik tunarungu lebih efektif dan sudah mecapai KKM dengan menggunakan LKS yang tekah dikembangkan oleh peneliti.

\section{Saran}

Berdasarkan kesimpulan yang diperoleh maka peneliti menyarankan untuk penelitian selanjutnya dilakukan sampai uji coba lapangan dan produksi massal agar melihan keefektifan bahan ajar yang dikembangkan. Sehingga LKS yang telah dikembangkan dapat bermanfaat untuk peserta didik tuna rungu

\section{Referensi}

[1] Agustiningsih, A. (2015). Pengembangan Desain E-Komik Tematik Berbasis Pada Pendidikan Lingkungan Hidup Dengan Aplikasi Macromedia-Flash Untuk KelaS Permulaan Sekolah Dasar. Pancaran Pendidikan, 4(4), 177-194.

[2] Khoiriyah, U., \& Rizki, S. (2017). Pengembangan Bahan Ajar Himpunan 
Matematika Yang Dikaitkan Dengan Nilai-Nilai Islam. AKSIOMA: Jurnal Program Studi Pendidikan Matematika, 6(3), 315. https://doi.org/10.24127/ajpm.v6i3.1142

[3] Harahap, H. S. (2015). Pengembangan Media Ajar Interaktif Biologi Berbasis Macromedia Flash Dalam Komputer Pada Materi Sistem Pencernaan Makanan Dan Pernapasan Manusia Untuk Kelas XI SMA/MA (PhD Thesis). UNIMED.

[4] Anggoro, B. S. (2015). Pengembangan Modul Matematika Dengan Strategi Problem Solvin Guntuk Mengukur Tingkat Kemampuan Berpikir Kreatif Matematis Siswa. Al-Jabar: Jurnal Pendidikan Matematika, 6(2), 121-130.

[5] Holidun, H., Masykur, R., Suherman, S., \& Putra, F. G. (2018). Kemampuan Pemecahan Masalah Matematis Kelompok Matematika Ilmu Alam dan Ilmu-Ilmu Sosial. Desimal: Jurnal Matematika, 1(1), 29-37.

[6] Avianty, D., \& Cipta, D. A. S. (2018). Pengembangan Multimedia Interaktif Berbasis Masalah Untuk Mendayagunakan Kemampuan Berpikir Tingkat Tinggi Pada Siswa Sekolah Dasar. AKSIOMA: Jurnal Program Studi Pendidikan Matematika, 7(2), 237. https://doi.org/10.24127/ajpm.v7i2.1503
[7] Sarimanah, E. (2016). Efeectivenes Of PQ4R Metacognitive Strategy Based Reading Learning Models in Junior High School. IJLECR-INTERNATIONAL JOURNAL OF LANGUAGE EDUCATION AND CULTURE REVIEW, 2(1), 74-81.

[8] Mega, S. D. (2012). Penggunaan Aplikasi Adobe Photoshop Dalam Meningkatkan Keterampilan Editing Foto Bagi Anak Tunarungu. E-JUPEKhu, 1(2)

[9] Dianita, A. (2014). Upaya meningkatkanhasil bel ajar bahasa indonesia melalui metode maternal reflektif bagi anak tunarungu kelas IV di SLB Sarawiyata Wlingi Kabupaten Blitar. Upaya meningkatkanhasil belajar bahasa indonesia melalui metode maternal reflektif bagi anak tunarungu kelas $I V$ di SLB Sarawiyata Wlingi Kabupaten Blitar/Agnes Dianita.

[10] Larasati, L. D. (2016). Pengembangan Permainan Kartu Domino Kimia Sebagai Media Pembelajaran Pada Materi Unsur Bagi Siswa Smalb Tunarungu (Development Of Domino Chemistry Card Games On The Subject Matter Of Unsure For Learning Media For Smalb DEAF STUDENTS). UNESA Journal of Chemical Education, 5(1). 
http://journal.unugiri.ac.id/index.php?journal=JaMES 